\title{
ALLEVIATION OF NACL STRESS IN SUMMER SQUASH 'ESKANDRANI' BY FOLIAR APPLICATION OF SALICYLIC ACID
}

\author{
Mohammed Wasfy Mohammed ELWAN*, Rewaa Salah Ahmed EL-SHATOURY \\ Suez Canal University, Faculty of Agriculture, Department of Horticulture \\ Ismailia, Egypt
}

Received: August 13, 2014; Accepted: October 16, 2014

\begin{abstract}
The experiment was performed to assess the possibility of overcoming $\mathrm{NaCl}$ salinity stress by foliar sprays of summer squash 'Eskandrani' with salicylic acid (SA) at the concentration of $10^{-6} \mathrm{M}$. NaCl treatment caused reduction of shoot fresh weight, leaf number per plant, fruit yield, concentrations of potassium in aerial parts, and the concentration of chlorophyll in leaves. Plants grown under salt stress conditions had higher shoot sodium concentrations than plants untreated with $\mathrm{NaCl}$. Foliar application of SA ameliorated partly the negative effect of $\mathrm{NaCl}$ treatment. The beneficial effect of SA was also observed in non-stressed plants, increasing the shoot potassium accumulation and leaf photosynthetic pigments status, and decreasing sodium accumulation in shoots.
\end{abstract}

Key words: salinity, salicylic acid, summer squash

\section{INTRODUCTION}

Soil fertility is decreasing globally due to enhanced degradation in the form of erosion, nutrient depletion, water scarcity, acidity, salinisation, organic matter depletion and poor drainage (Cakmak 2002). Salinity is one of the main environmental factors responsible for the decreased productivity of a wide variety of crops in arid and semi-arid regions. Each year about 40000 ha of land becomes unavailable for agricultural production worldwide due to salinisation, and approximately 50\% of irrigated lands are currently affected by salinity (Hu $\&$ Schmidhalter 2005).

Salt stress affects plants metabolism, which results in decreased growth and yields. Excess of salts in the soil solution adversely affects plant growth either through inhibition of water uptake or specific ion effects. Specific ion effects may cause direct toxicity, while the insolubility and competitive absorption of ions may affect the nutritional imbalance of plants (Greenway \& Munns 1980). In most cases, soil salinity has been associated with an increase in the uptake rate of $\mathrm{Na}^{+}$or reduction of the absorption rates of $\mathrm{K}^{+}$and $\mathrm{Ca}^{2+}$ (Neel et al. 2002). Also, a high medium salinity induces serious metabolic perturbations in plants, as it generates reactive oxygen species (ROS), which disturb the cellular redox system in favour of oxidised forms thereby creating an oxidative stress that may damage DNA, inactivate enzymes and cause lipid peroxidation (Smirnoff 1993).

The strategies for alleviation of salt stress include breeding of salt-resistant cultivars, leaching the excess of soluble salts from upper to lower soil depths and flushing soils containing salt crusts at the surface (Qadir et al. 2000). Selection of salt tolerant plants is limited by high variability in soil salinity and environmental interactions. Leaching the excess of soluble salts from soil surface layer requires huge amounts of water and its impact on alleviation of salinity is not stable in growing season, at least in arid and semi-arid regions. Flushing method also does not have practical significance because efficiency of this treatment in alleviation of soil salinity is low. Therefore, the development of methods/strategies to ameliorate deleterious effects of salt tolerance on plants has received considerable 
attention. One of these strategies is the use of salicylic acid (SA) (Hayat et al. 2010).

SA naturally occurs in plants in very low concentration and participates in the regulation of stomatal closure, nutrient uptake, protein synthesis, inhibition of ethylene biosynthesis and transpiration (Khan et al. 2003; Shakirova et al. 2003). SA plays a protective role against plant stress (Güneş et al. 2007). Many studies have showed that SA induces increasing tolerance to salinity and osmotic stress in maize (Tuna et al. 2007; Agam 2013), wheat (AlHakimi \& Hamada 2001; Arfan et al. 2007), barley (Fayez \& Bazaid 2014), mung bean (Nazar et al. 2011; Khan et al. 2014), alfalfa (Palma et al. 2013), Indian mustard (Yusuf et al. 2008), Arabidopsis seedlings (Borsani et al. 2001), tomato (Tari et al. 2002, 2004; Szepesi et al. 2005, 2009) and cucumber (Dong et al. 2011; Hao et al. 2012). However, the effect of SA on plant growth and metabolism is still a matter of controversy in regards to different plant species, salt stress intensity and timing of application, as well as used rates (Horváth et al. 2007).

It has been reported that exogenous application of SA was able to enhance the photosynthetic rate and also maintain the stability of membranes, thereby improved the growth of salinity stressed barley (El Tayeb 2005), mung bean (Nazar et al. 2011) and alfalfa (Palma et al. 2013). Kaydan et al. (2007) observed that under both saline and non-saline conditions pre-sowing soaking treatment of seeds with SA positively affected the osmotic potential, shoot and root dry mass, $\mathrm{K}^{+} / \mathrm{Na}^{+}$ratio and contents of photosynthetic pigments (chlorophyll a, $\mathrm{b}$ and carotenoids) in wheat seedlings. Foliar application of SA improved photosynthetic characteristics of leguminous plants and increased salt tolerance by increasing antioxidant metabolism (Nazar et al. 2011; Palma et al. 2013).

Summer squash is one of the most popular and widely used vegetable crops in the world. Approximately 1.8 million ha are planted yearly with squash, pumpkin and gourd all over the world and yielding 24.62 million tons with an average of 13.7 tons $\cdot$ ha $^{-1}$. Egypt produced approximately 559600 tons of squash, pumpkin and gourd with an average of 18.2 tons $\cdot$ ha $^{-1}$ (FAOSTAT 2012).
Large part of literature indicates that exogenous application of SA to the salinity-stressed plants can alleviate the toxic effects and improve vegetative and reproductive responses (Tari et al. 2004; Szepesi et al. 2005; El Tayeb 2005; Kaydan et al. 2007; Yusuf et al. 2008). However, there is little information concerning summer squash. Therefore, the aim of the study was to evaluate the effects of foliar application of SA on plants growth and fruits yield of 'Eskandrani' summer squash (Cucurbita pepo L.) grown under saline and non-saline conditions.

\section{MATERIALS AND METHODS}

The pot experiment was conducted under open-field conditions during the spring (mid of March to the end of May) of 2013 and repeated in 2014. Summer squash 'Eskadrani' seeds were sown in $30 \times 30 \mathrm{~cm}$ (diameter $\times$ depth) plastic pots filled with sand with $\mathrm{pH} 8.2$, electrical conductivity (EC) $0.46 \mathrm{dS} \cdot \mathrm{m}^{-1}, \mathrm{Ca}^{2+}(0.4 \mathrm{mmol}), \mathrm{Mg}^{2+}(0.3 \mathrm{mmol})$, $\mathrm{K}^{+}(0.3 \mathrm{mmol}), \mathrm{Na}^{+}(3.0 \mathrm{mmol}), \mathrm{HCO}_{3}{ }^{-}(1.6 \mathrm{mmol})$, $\mathrm{Cl}^{-}(3.0 \mathrm{mmol})$ and $\mathrm{SO}_{4}{ }^{2-}(0.05 \mathrm{mmol})$. The environmental conditions during experiment were as follows: a $14 \mathrm{~h}$ photoperiod, temperature $35-40 / 23$ $26{ }^{\circ} \mathrm{C}$ in day/night, and a relative humidity $50-55 \%$.

All the plants were fertigated four times a week, initially with $250 \mathrm{ml}$ of the nutrient solution (20-20-20 NPK plus micronutrients) per pot and from the middle of April to the end of experiment with $500 \mathrm{ml}$. EC of nutrient solutions for combinations without use of $\mathrm{NaCl}$ was $2 \mathrm{dS} \cdot \mathrm{m}^{-1}$, and $5 \mathrm{dS} \cdot \mathrm{m}^{-}$ ${ }^{1}$ for combinations with $50 \mathrm{mM} \mathrm{NaCl}$. After 3 weeks of cultivation following treatments were initiated:

1. Plants fertigated with nutrient solution (20-2020 NPK plus micronutrients) and sprayed twice a week with distilled water (control).

2. Plants fertigated with nutrient solution and sprayed with $10^{-6} \mathrm{M}$ SA solution twice a week.

3. Plants fertigated with nutrient solution with addition of $5 \times 10^{-2} \mathrm{M} \mathrm{NaCl}$ and sprayed twice a week with distilled water.

4. Plants fertigated with nutrient solution with addition of $5 \times 10^{-2} \mathrm{M} \mathrm{NaCl}$ and sprayed twice a week with $10^{-6} \mathrm{M}$ SA solution.

At the end of the experiment each salt-treated pot received $26 \mathrm{~g} \mathrm{NaCl}$. 
SA concentration $\left(10^{-6} \mathrm{M}\right)$ was selected as earlier proved beneficial for growth of the same cultivar under field conditions (Elwan \& El-Shatoury 2012). The volume of water or SA solution ranged from 20 to $50 \mathrm{ml}$ per pot each time, depending on plant size. SA was initially dissolved in a few drops of dimethyl sulfoxide and the final volume was reached using distilled water. The $\mathrm{pH}$ was adjusted with $\mathrm{KOH}(1.0 \mathrm{~N})$ to a value of 7.0. All sprays were applied in the morning (8:00-9:00 a.m.). Experiment was arranged in completely randomised design. Each treatment was replicated three times and each replicate included six pots.

\section{Plant growth and yield}

Fresh weights of fruits were recorded from the second week of April and continued for 4 weeks. Fruits were harvested when reached the size of over $10 \mathrm{~cm}$. After the last harvest, plants were uprooted and the fresh weight of shoots and number of leaves per plant were determined.

\section{Total chlorophyll concentration in leaves}

Chlorophyll was determined according to $\mathrm{Li}$ chenthaler and Wellburn (1983) in the third leaf of the top of the 6-week-old seedlings, in three samples per replicate. Results were expressed as $\mathrm{mg} \cdot \mathrm{g}^{-1}$ fresh weight.

\section{Concentrations of $\mathrm{K}^{+}$and $\mathrm{Na}^{+}$in shoots}

Three shoots per replicate were dried in an oven at $70{ }^{\circ} \mathrm{C}$ for 3 days to determine $\mathrm{K}^{+}$and $\mathrm{Na}^{+}$ concentration with flame photometer, according to Brown and Lilleland (1946). Powdered material was digested using a mixture of sulphuric acid and hydrogen peroxide.

\section{Data analysis}

The results were evaluated using two-ways ANOVA. The effects of salt and SA addition were evaluated by Fisher's $F$-test, followed by Duncan's multiple range test for comparing $\mathrm{NaCl} \times \mathrm{SA}$ combinations. All tests were performed at significance levels $p=0.001,0.01$ and 0.05 . Calculations were carried out using the software package Statistica TM for Windows version 6.1 (Statsoft 2001, Tulsa, OK, USA). Correlations were evaluated using Correlation Matrices (Statsoft 2001).

\section{RESULTS}

In both years of study $\mathrm{NaCl}$-stressed plants had less numbers of leaves, lower fresh weight of shoots and lower fruit yield compared to control plants. Mature leaves of NaCl-treated plants turned from green to yellow and then brown colour, and died at the end of the experiment. Compared to control, plants sprayed with SA had 2.3 and 1.4 times more leaves and 3.2 and 2.5 times higher fresh weight in 2013 and 2014, respectively. NaCl-stressed plants did not yield fruits in 2013 and a few in 2014; thus, SA application enabled fruiting although at very low level (Table 1). Regarding the fruit yield, application of SA increased the yield from 59\% to 65\% (depending on year) under non-saline conditions. However, the efficiency of SA application on $\mathrm{NaCl}-$ stressed plants was more pronounced for increasing the yield in comparison to salt-stressed plants that were not treated with SA (Table 1).

In both seasons, salinity and SA affected leaf chlorophyll concentration, content of $\mathrm{K}^{+}$and $\mathrm{Na}^{+}$ and $\mathrm{K}^{+} / \mathrm{Na}^{+}$ratio in shoots (Table 2). Content of leaf chlorophyll and $\mathrm{K}^{+}$in shoots, and $\mathrm{K}^{+} / \mathrm{Na}^{+}$ratio decreased as a result of $\mathrm{NaCl}$ application in both years of study (Table 2). Leaf chlorophyll and $\mathrm{K}^{+}$concentrations in shoots were about $30 \%$ lower in $\mathrm{NaCl}-$ stressed plants in comparison with control, whereas shoot concentration of $\mathrm{Na}^{+}$increased by about five times, therefore $\mathrm{K}^{+} / \mathrm{Na}^{+}$ratio decreased by about three times. In both years of the study, SA application increased leaf chlorophyll and shoot $\mathrm{K}^{+}$concentrations in control plants but did not change shoot $\mathrm{Na}^{+}$level. Application of SA on NaCl-treated plants caused increase of leaf chlorophyll, shoot $\mathrm{K}^{+}$and $\mathrm{K}^{+} / \mathrm{Na}^{+}$ratio, and decrease of $\mathrm{Na}^{+}$concentration in shoots but the alleviation did not reach contents present in control plants (Table 2).

Leaves number and fruits weight per plant were positively correlated with the concentration of the total chlorophyll in leaves, and with potassium and $\mathrm{K}^{+} / \mathrm{Na}^{+}$ratio in aerial plant parts whereas negatively with $\mathrm{Na}^{+}$concentration in aerial plant parts (Table 3). 
Table 1. Impact of $\mathrm{NaCl}$ and foliar application of salicylic acid (SA) on leaf number, fresh weight of shoots and fruit yield of summer squash 'Eskandrani'

\begin{tabular}{lccccccc}
\hline \multirow{2}{*}{$\mathrm{NaCl}$} & \multirow{2}{*}{ Salicylic acid } & \multicolumn{2}{c}{ Leaf no. per plant } & \multicolumn{2}{c}{$\begin{array}{c}\text { Fresh weight of shoots } \\
\left(\mathrm{g} \cdot \text { plant }^{-1}\right)\end{array}$} & \multicolumn{2}{c}{$\begin{array}{c}\text { Fresh weight of fruits } \\
\left(\mathrm{g} \cdot \text { plant }^{-1}\right)\end{array}$} \\
\cline { 2 - 8 } & & 2013 & 2014 & 2013 & 2014 & 2013 & 2014 \\
\hline \multirow{2}{*}{0} & 0 & $11.6 \mathrm{ab}$ & $12.6 \mathrm{ab}$ & $169 \mathrm{a}$ & $178 \mathrm{a}$ & $70 \mathrm{~b}$ & $75 \mathrm{~b}$ \\
& $10^{-6} \mathrm{M}$ & $13.2 \mathrm{a}$ & $14.8 \mathrm{a}$ & $179 \mathrm{a}$ & $184 \mathrm{a}$ & $116 \mathrm{a}$ & $119 \mathrm{a}$ \\
\hline \multirow{2}{*}{$5 \times 10^{-2} \mathrm{M}$} & 0 & $4.0 \mathrm{c}$ & $7.0 \mathrm{c}$ & $24.6 \mathrm{c}$ & $30.6 \mathrm{c}$ & $0.0 \mathrm{~d}$ & $4.0 \mathrm{~d}$ \\
& $10^{-6} \mathrm{M}$ & $9.2 \mathrm{~b}$ & $10.0 \mathrm{~b}$ & $80.5 \mathrm{~b}$ & $88.8 \mathrm{~b}$ & $20.0 \mathrm{c}$ & $23.3 \mathrm{c}$ \\
\hline \multicolumn{2}{l}{ Significance of tested effects } & & & & & & \\
\hline NaCl & & $* * *$ & $* * *$ & $* * *$ & $* * *$ & $* * *$ & $* * *$ \\
Salicylic acid (SA) & $*$ & $*$ & $* *$ & $* *$ & $* * *$ & $* * *$ \\
NaCl*SA & $\mathrm{NS}$ & $\mathrm{NS}$ & $*$ & $* *$ & $*$ & $*$ \\
\hline
\end{tabular}

Note: weight of died plants and no fruits was counted as zero

Values are the means of 6 samples per replicate (three replicates). Values followed by the same letter within a column are not significantly different at the $0.05 \%$ level of probability according to Duncan's multiple range test

$* * *, * *$ and $*$ significant at $0.1 \%, 1 \%$ and $5 \%$; NS: not significant

Table 2. Impact of $\mathrm{NaCl}$ and foliar application of salicylic acid (SA) on total chlorophyll in leaves and potassium and sodium concentration in shoots of summer squash 'Eskandrani'

\begin{tabular}{|c|c|c|c|c|c|c|c|c|c|}
\hline \multirow{2}{*}{$\mathrm{NaCl}$} & \multirow{2}{*}{ Salicylic acid } & \multicolumn{2}{|c|}{$\begin{array}{l}\text { Total chlorophyll } \\
\left(\mathrm{mg} \cdot \mathrm{g}^{-1} \mathrm{FW}\right)\end{array}$} & \multicolumn{2}{|c|}{$\begin{array}{c}\mathrm{K}^{+} \\
\left(\mathrm{mg} \cdot \mathrm{g}^{-1} \mathrm{DW}\right)\end{array}$} & \multicolumn{2}{|c|}{$\begin{array}{c}\mathrm{Na}^{+} \\
\left(\mathrm{mg} \cdot \mathrm{g}^{-1} \mathrm{DW}\right)\end{array}$} & \multicolumn{2}{|c|}{$\mathrm{K}^{+} / \mathrm{Na}^{+}$ratio } \\
\hline & & 2013 & 2014 & 2013 & 2014 & 2013 & 2014 & 2013 & 2014 \\
\hline \multirow{2}{*}{0.0} & 0.0 & $0.85 \mathrm{~b}$ & $0.91 \mathrm{~b}$ & $32.0 \mathrm{~b}$ & $33.5 \mathrm{~b}$ & $0.95 \mathrm{c}$ & $1.05 \mathrm{c}$ & $33.8 \mathrm{~b}$ & $32.1 \mathrm{~b}$ \\
\hline & $10^{-6} \mathrm{M}$ & $1.04 \mathrm{a}$ & $1.09 \mathrm{a}$ & $36.5 \mathrm{a}$ & $37.5 \mathrm{a}$ & $0.85 \mathrm{c}$ & $0.95 \mathrm{c}$ & $43.1 \mathrm{a}$ & $39.6 \mathrm{a}$ \\
\hline \multirow{2}{*}{$5 \times 10^{-2} \mathrm{M}$} & 0.0 & $0.61 \mathrm{c}$ & $0.64 \mathrm{~d}$ & $21.5 \mathrm{~d}$ & $22.5 \mathrm{~d}$ & $5.75 \mathrm{a}$ & $6.25 \mathrm{a}$ & $3.7 \mathrm{~d}$ & $3.6 \mathrm{~d}$ \\
\hline & $10^{-6} \mathrm{M}$ & $0.76 \mathrm{~b}$ & $0.79 \mathrm{c}$ & $28.0 \mathrm{c}$ & $28.5 \mathrm{c}$ & $4.25 \mathrm{~b}$ & $4.75 \mathrm{~b}$ & $6.6 \mathrm{c}$ & $6.0 \mathrm{c}$ \\
\hline \multicolumn{10}{|c|}{ Significance of tested effects } \\
\hline \multicolumn{2}{|l|}{$\mathrm{NaCl}$} & $* *$ & $* * *$ & $* * *$ & $* * *$ & $* * *$ & $* * *$ & **** & $* * *$ \\
\hline \multicolumn{2}{|c|}{ Salicylic acid (SA) } & $*$ & $* *$ & $* *$ & ** & $* *$ & $* *$ & $* * *$ & $* *$ \\
\hline \multicolumn{2}{|l|}{$\mathrm{NaCl} * \mathrm{SA}$} & NS & * & $*$ & $*$ & $*$ & $*$ & ** & $*$ \\
\hline
\end{tabular}

Values are the means of three samples per replicate (three replicates). Values followed by the same letter within a column are not significantly different at the $0.05 \%$ level of probability according to Duncan's multiple range test

$* * *, * *$ and $*$ significant at $0.1 \%, 1 \%$ and $5 \%$; NS: not significant

Table 3. Correlation coefficients between the morphological traits and chlorophyll content in leaves, and $\mathrm{K}^{+}$and $\mathrm{Na}^{+}$contents in the shoots

\begin{tabular}{lcccc}
\hline & Chlorophyll & $\mathrm{K}^{+}$ & $\mathrm{Na}^{+}$ & $\mathrm{K}^{+} / \mathrm{Na}^{+}$ \\
\hline Leaf No. & $0.8^{* * *}$ & $0.8^{* * *}$ & $-0.7 * *$ & $0.7 * *$ \\
\hline $\begin{array}{l}\text { Shoot fresh } \\
\text { weight }\end{array}$ & $0.8^{* * *}$ & $0.9 * * *$ & $-0.9 * * *$ & $0.9 * * *$ \\
\hline $\begin{array}{l}\text { Fruit fresh } \\
\text { weight }\end{array}$ & $0.9 * * *$ & $0.9 * * *$ & $-0.9 * * *$ & $0.9 * * *$ \\
\hline
\end{tabular}

$* * *$ and $* *$ significant at $0.1 \%$ and $1 \%$

\section{DISCUSSION}

Morphological traits - leaves number and fruits yield in addition to plant fresh weight and chemical parameters, such as chlorophyll and $\mathrm{K}^{+}$ contents as well as $\mathrm{K}^{+} / \mathrm{Na}^{+}$ratio decreased as a result of soil application of $50 \mathrm{mM} \mathrm{NaCl}$, whereas $\mathrm{Na}^{+}$ content increased. This is in accordance with findings in experiments on strawberry (Kaya et al. 2001), cucumber (Kaya et al. 2003; Dong et al. 2011), melon (Kaya et al. 2007), eggplant (Elwan 
2010), maize (Agami 2013), mung bean (Khan et al. 2014) and barley (Fayez \& Bazaid 2014). It is well known that salt stress suppresses plant growth due to reduction in water availability or to excessive $\mathrm{Na}^{+}$ ion accumulation in plant tissues (Güneş et al. 1995) and reduce the availability of nutrients, especially $\mathrm{K}^{+}$(Liebersbach et al. 2004; Cakmak 2005). The reduction in photosynthesis has been associated with the disturbance in homeostasis of $\mathrm{Na}^{+}$ions and essential mineral nutrients (Güneş et al. 2007; Keutgen \& Pawelzik 2009), stomatal closure (Steduto et al. 2000) and the increased production of ROS in chloroplasts (Meneguzzo et al. 1999), which causes membrane damage.

Amelioration of the adverse effects of salinity stress on plants growth and yield by application of SA on summer squash was not reported. In our experiment, the foliar spraying with SA was beneficial for plants growth, increased fresh weight and chlorophyll content that might be due to the selective uptake and accumulation of more potassium and less sodium. Therefore, the adaptive mechanism of plants treated with $10^{-6}$ M SA for salinity may be explained in part by more selective accumulation of nutrients, especially $\mathrm{K}^{+}$. These results are in agreement with the findings of Binzel and Reuveni (1994), Güneş et al. (2005) and Al-Hakimi and Hamada (2001) who reported that salt-tolerant plants exhibit greater $\mathrm{K}^{+} / \mathrm{Na}^{+}$ratio than susceptible plants. In our study selectivity in ions accumulation was also connected with higher tolerance to salt stress caused by SA application. The results of Azooz (2009) and Kha et al. (2014) showed that SA application modifies $\mathrm{Na}^{+}$and $\mathrm{K}^{+}$selectivity uptake and decreases $\mathrm{Na}^{+} / \mathrm{K}^{+}$ratio, which helps in lowering membrane damage. The protective role of $\mathrm{SA}$ in membrane integrity and regulation of ion uptake has also been reported by El-Tayeb (2005), Güneş et al. (2007), Nazar et al. (2011). SA might be involved in mobilisation of internal tissue nitrate and chlorophyll biosynthesis that strengthens the functional state of the photosynthetic machinery in plants (Shi et al. 2006; Elwan \& El-Shatoury 2012; Nazar et al. 2011; Khan et al. 2014; Fayez \& Bazaid 2014). The above statements were confirmed in our study by increasing the leaf number, plants fresh weight and chlorophyll content under saline and non-saline conditions.
In conclusion, salinity stress caused by $\mathrm{NaCl}$ inhibited plants growth and fruits yield of summer squash 'Escandrani'. Foliar application of SA at the concentration of $10^{-6} \mathrm{M}$ alleviated the salt stress. The foliar application of SA was also beneficial for non-stressed plants. It caused the $\mathrm{K}^{+}$accumulation in shoots, increased chlorophyll concentration and decreased $\mathrm{Na}^{+}$accumulation in shoots.

\section{REFERENCES}

Agami R.A. 2013. Alleviating the adverse effects of $\mathrm{NaCl}$ stress in maize seedlings by pretreating seeds with salicylic acid and 24-epibrassinolide. South African J. Bot. 88: 171-177. DOI: 10.1016/j.sajb.2013.07.019.

Al-Hakimi A.M.A., Hamada A.M. 2001. Counteraction of salinity stress on wheat plants by grain soaking in ascorbic acid, thiamin or sodium salicylate. Biol. Plant. 44(2): 253-261. DOI: 10.1023/A:1010255526903.

Arfan M., Athar H.R., Ashraf M. 2007. Does exogenous application of salicylic acid through the rooting medium modulate growth and photosynthetic capacity in two differently adapted spring wheat cultivars under salt stress? J. Plant Physiol. 164(6): 685-694. DOI: $10.1016 /$ j.jplph.2006.05.010.

Azooz M.M. 2009. Salt stress mitigation by seed priming with salicylic acid in two faba bean genotypes differing in salt tolerance. Int. J. Agric. Biol. 11: 343-350.

Binzel M.L., Reuveni M. 1994. Cellular mechanisms of salt tolerance in plant cells. In: J. Janick (Ed.), Horticultural Reviews. New York Wiley 16 pp. 33-69. DOI: 10.1002/9780470650561.ch2.

Borsani O., Valpuesta V., Botella M.A. 2001. Evidence for a role of salicylic acid in the oxidative damage generated by $\mathrm{NaCl}$ and osmotic stress in Arabidopsis seedlings. Plant Physiology 126(3): 1024-1030. DOI: $10.1104 / p p .126 .3 .1024$.

Brown J.D., Lilleland O. 1946. Rapid determination of potassium and sodium in plant material and soil extracts by flame photometry. Proc. Amer. Soc. Hort. Sci. 48: 341-346.

Cakmak I. 2002. Plant nutrition research: Priorities to meet human needs for food in sustainable ways. Plant Soil 247: 3-24.

Cakmak I. 2005. The role of potassium in alleviating detrimental effects of biotic stresses in plants. J. Plant Nutr. Soil Sci. 168(4): 521-530. DOI: 10.1002/jpln.200420485. 
Dong Ch-J., Wang X-L., Shang Q-M. 2011. Salicylic acid regulates sugar metabolism that confers tolerance to salinity stress in cucumber seedlings. Sci. Hortic. 129(4): 629-636. DOI:10.1016/j.scienta.2011.05.005.

El-Tayeb M.A. 2005. Response of barley grains to the interactive effect of salinity and salicylic acid. Plant Growth Regul. 45(3): 215-224. DOI: 10.1007/s10725-005-4928-1.

Elwan M.W.M. 2010. Ameliorative effects of di-potassium hydrogen orthophosphate on salt-stressed eggplant. J. Plant Nutr. 33(11): 1593-1604. DOI: 10.1080/01904167.2010.496884.

Elwan M.W.M., El-Shatoury R.S.A. 2012. Salicylic acid positively affected plant growth, photosynthetic leaf pigments and fruit yield of summer squash (Cucurbita pepo L.) grown under different N-levels. Mansoura J. Plant Production 3(7): 2123-2138.

FAOSTAT 2012. http://http://faostat3.fao.org

Fariduddin Q., Hayat S., Ahmad A. 2003. Salicylic acid influences net photosynthetic rate, carboxylation efficiency, nitrate reductase activity and seed yield in Brassica juncea. Photosynthetica 41(2): 281-284. DOI: 10.1023/B:PHOT.0000011962.05991.6c.

Fayez K.A., Bazaid S.A. 2014. Improving drought and salinity tolerance in barley by application of salicylic acid and potassium nitrate. Journal of the Saudi Society of Agricultural Sciences 13(1): 4555. DOI: 10.1016/j.jssas.2013.01.001.

Greenway H., Munns R. 1980. Mechanisms of salt tolerance in nonhalophytes. Ann. Rev. Plant Physiol. 31: 149190. DOI: 10.1146/annurev.pp.31.060180.001053.

Güneş A., İnal A., Alpaslan M., Cicek N., Guneri E., Eraslan F., Guzelordu T. 2005. Effects of exogenously applied salicylic acid on the induction of multiple stress tolerance and mineral nutrition in maize (Zea mays L.). Arch. Agron. Soil Sci. 51(6): 687-695. DOI:10.1080/03650340500336075.

Güneş A., İnal A., Alpaslan M., Eraslan F., Bagci E.G., Cicek N. 2007. Salicylic acid induced changes on some physiological parameters symptomatic for oxidative stress and mineral nutrition in maize (Zea mays L.) grown under salinity. J. Plant Physiol. 164(6): 728-736. DOI: 10.1016/j.jplph.2005.12.009.

Güneş A., İnal A., Alpaslan M., Aktaş M. 1995. Effects of salinity stress on stomatal resistance, proline, chlorophyll and mineral composition of potato ( $\mathrm{So}$ lanum tuberosum L.). Soil Fertilitiy and Feretilizer Manag. Kuşadası, Turkey pp. 235-241.
Hao J.H., Dong C.J., Zhang Z.G., Wang X.L., Shang Q.M. 2012. Insights into salicylic acid responses in cucumber (Cucumis sativus L.) cotyledons based on a comparative proteomic analysis. Plant Sci. 187: 69-82. DOI: 10.1016/j.plantsci.2012.01.001.

Hayat Q., Hayat S., Irfan M., Ahmad A. 2010. Effect of exogenous salicylic acid under changing environment: A review. Environ. Exp. Bot. 68(1): 14-25. DOI: 10.1016/j.envexpbot.2009.08.005.

Horváth E., Szalai G., Janda T. 2007. Induction of a biotic stress tolerance by salicylic acid signalling. J. Plant Growth Regul. 26(3): 290-300. DOI: 10.1007/s00344-007-9017-4.

$\mathrm{Hu}$ Y., Schmidhalter U. 2005. Drought and salinity: A comparison of their effects on mineral nutrition of plants. J. Plant Nutr. Soil Sci. 168(4): 541-549. DOI: 10.1002/jpln.200420516.

Kaya C., Tuna A.L., Ashraf M., Altunlu H. 2007. Improved salt tolerance of melon (Cucumis melo L.) by the addition of proline and potassium nitrate. Environ. Exp. Bot. 60(3): 397-403. DOI: 10.1016/j.envexpbot.2006.12.008.

Kaya C., Higgs D., Ince F., Murillo-Amador B., Cakir A., Sakar E. 2003. Ameliorative effects of potassium phosphate on salt stressed pepper and cucumber. J. Plant Nutr. 26(4): 807-820. DOI: 10.1081/PLN120018566.

Kaya C., Kirnak H., Higgs D. 2001. An experiment to investigate the ameliorative effects of foliar potassium phosphate sprays on salt-stressed strawberry plants. Aust. J. Agric. Res. 52(10): 995-1000. DOI: 10.1071/AR00164

Kaydan D., Yagmur M., Okut N. 2007. Effects of Salicylic acid on the growth and some physiological characters in salt stressed wheat (Triticum aestivum L.). Tarim Bilimleri Dergisi 13(2): 114-119.

Keutgen A.J., Pawelzik E. 2009. Impact of $\mathrm{NaCl}$ stress on plant growth and mineral nutrient assimilation in two cultivars of strawberry. Environ. Exp. Bot. 65: 170-176. DOI: 10.1016/j.envexpbot.2008.08.002.

Khan W., Prithiviraj B., Smith D.L. 2003. Photosynthetic responses of corn and soybean to foliar application of salicylates. J. Plant. Physiol. 160(5): 485-492. DOI: 10.1078/0176-1617-00865.

Khan M.I.R., Asgher M., Khan N.A. 2014. Alleviation of salt-induced photosynthesis and growth inhibition by salicylic acid involves glycinebetaine and ethylene in mungbean (Vigna radiata L.). Plant 
Physiol. Biochem. 80: 67-74. DOI: 10.1016/j.plaphy.2014.03.026.

Lichtenthaler H.K., Wellburn A.R. 1983. Determination of total carotenoids and chlorophylls a and b of leaf extracts in different solvents. Biochem. Soc. Trans. 11: 591-592.

Liebersbach H., Steingrobe B, Claassen N. 2004. Roots regulate ion transport in the rhizosphere to counteract reduced mobility in dry soil. Plant and Soil 260(1-2): 79-88. DOI: 10.1023/B:PLSO.0000030191.92338.6a.

Meneguzzo S., Navarri-Izzo F., Izzo R. 1999. Antioxidative responses of shoots and roots of wheat to increasing $\mathrm{NaCl}$ concentrations. J. Plant Physiol. 155(2): $\quad 274-280 . \quad$ DOI: $10.1016 / \mathrm{S} 0176-$ 1617(99)80019-4.

Nazar R., Iqbal N., Syeed S., Khan N.A. 2011. Salicylic acid alleviates decreases in photosynthesis under salt stress by enhancing nitrogen and sulfur assimilation and antioxidant metabolism differentially in two mungbean cultivars. J. Plant Physiol. 168(8): 807815. DOI: org/10.1016/j.jplph.2010.11.001.

Neel J.P.S., Alloush G.A., Belesky D.P., Clapham W.M. 2002. Influence of rhizosphere ionic strength on mineral composition, dry matter yield and nutritive value of forage chicory. J. Agron. Crop Sci. 188: 398-407. DOI: 10.1046/j.1439-037X.2002.00593.x.

Qadir M., Ghafoor A., Murtaza G. 2000. Amelioration strategies for saline soils: a review. Land Degradation and Development 11: 501-521. DOI: 10.1002/1099-145X(200011/12)11:6<501::AIDLDR405>3.0.CO;2-S.

Palma F., López-Gómez M., Tejera N.A., Lluch C. 2013. Salicylic acid improves the salinity tolerance of Medicago sativa in symbiosis with Sinorhizobium meliloti by preventing nitrogen fixation inhibition. Plant Sci. 208: 75-82. DOI: 10.1016/j.plantsci.2013.03.015.

Rai M.K., Kalia R.K., Singh R., Gangola M.P., Dhawan A.K. 2011. Developing stress tolerant plants through in vitro selection. An overview of the recent progress. Environ. Exp. Bot. 71(1): 89-98. DOI: 10.1016/j.envexpbot.2010.10.021.

Shakirova F.M., Sakhabutdinova A.R., Bezrukova M.V., Fatkhutdinova R.A., Fatkhutdinova D.R. 2003. Changes in the hormonal status of wheat seedlings induced by salicylic acid and salinity. Plant Sci. 164(3): 317-322. DOI:10.1016/S0168-9452(02)00415-6.

Shannon M.C. 1985. Principles and strategies in breeding for higher salt tolerance. Plant Soil 89: 227-241. DOI: $10.1007 / \mathrm{BF} 02182244$.
Shi Q., Bao Z., Zhu Z., Ying Q., Qian Q. 2006. Effects of different treatments of salicylic acid on heat tolerance, chlorophyll fluorescence, and antioxidant enzyme activity in seedlings of Cucumis sativa L. Plant Growth Regul. 48(2): 127-135. DOI: 10.1007/s10725-005-5482-6.

Smirnoff N. 1993. The role of active oxygen in response of plants to water deficit and desiccation. New Phytologist 125: 27-58. DOI: 10.1111/j.14698137.1993.tb03863.x.

Statsoft Inc. 2001. STATISTICA fuer Windous [Software-system fuer Datenanalyse] Version 6. www.Statsoft.com.

Steduto P., Albrizio R., Giorio P., Sorrentino G. 2000. Gas-exchange response and stomatal and non-stomatal limitations to carbon assimilation of sunflower under salinity. Environ. Exp. Bot. 44(3): 243-255. DOI: 10.1016/S0098-8472(00)00071X.

Szepesi Á., Csiszár J., Gémes K., Horváth E., Horváth F., Simon M.L., Tari I. 2009. Salicylic acid improves acclimation to salt stress by stimulating abscisic aldehyde oxidase activity and abscisic acid accumulation, and increases $\mathrm{Na}^{+}$content in leaves without toxicity symptoms in Solanum lycopersicum L. J. Plant Physiol. 166(9): 914-925. DOI: 10.1016/j.jplph.2008.11.012.

Szepesi Á., Csiszár J., Bajkán Sz., Gémes K., Horváth F., Erdei L., Deér A.K., Simon M.L., Tari I. 2005. Role of salicylic acid pre-treatment on the acclimation of tomato plants to salt- and osmotic stress. Acta Biologica Szegediensis 49: 123-125.

Tari I., Csiszár J., Szalai G., Horváth F., Pécsváradi A., Kiss G., Szepesi A., Szabó M., Erdei L. 2002. Acclimation of tomato plants to salinity stress after a salicylic acid pre-treatment. Acta Biologica Szegediensis 46: 55-56.

Tari I., Simon L.M., Deér K.A., Csiszár J., Bajkán Sz., Kis G., Szepesi Á. 2004. Influence of salicylic acid on salt stress acclimation of tomato plants: oxidative stress responses and osmotic adaptation. Acta Physiol. Plant. Book of Abstracts pp. 237.

Tuna A.L., Kaya C., Dikilitas M., Yokas I., Burun B., Altunlu H. 2007. Comparative effects of various salicylic acid derivatives on key growth parameters and some enzyme activities in salinity stressed maize (Zea mays L.) plants. Pak. J. Bot. 39(3): 787-798.

Yusuf M., Hasan S.A., Ali B., Hayat S., Fariduddin Q., Ahmad A. 2008. Effect of salicylic acid on salinity-induced changes in Brassica juncea. J. Integrative Plant Biol. 50(9): 1096-1102. DOI: 10.1111/j.1744-7909.2008.00697.x. 